\title{
FROM COLONISATION TO GLOBALISATION: THE IMPACT OF ENGLISH ON GREEK, WITH PARTICULAR REFERENCE TO THE DIALECT OF CYPRUS*
}

\author{
Stavroula Varela**
}

\begin{abstract}
The constant 'invasion' of Anglicisms in languages across the world has been a widely studied phenomenon. This paper focuses on a particularly interesting case, seeking, first, to trace the beginnings of the influence of English on the Greek dialect spoken in Cyprus and, second, to account for its continuous increase in contemporary history up to the present. The narrative is built upon a number of comparisons regarding the position of English, both synchronic and diachronic: from colonialism in Cyprus and other parts of the world, to the strive for independence, and on to the role the island pays in current global affairs.

Key words: Anglicisms, linguistic influence, Greek dialect spoken in Cyprus, colonialism.

Resumen: La constante invasión de las lenguas en el mundo ha sido un fenómeno ampliamente estudiado. Este artículo se centra en un caso particularmente interesante, buscando, en primer lugar, rastreando los comienzos de la influencia del inglés en el dialecto del griego que se habla en Chipre y, en segundo lugar, explicar su continuo crecimiento en la historia contemporánea hasta el presente. La narrativa se construye sobre un número de comparaciones relativas a la posición del inglés, ambas sincrónica y diacrónicamente: Desde el colonialismo en Chipre y otras partes del mundo, hasta el esfuerzo por independizarse, y en el papel que juega la isla en los asuntos globales de hoy. Palabras clave: Anglicismos, influencia lingüística, dialecto griego hablado en Chipre, colonialismo.
\end{abstract}

\section{INTRODUCTION}

Cyprus, located in the Eastern corner of the Mediterranean Sea, has been a place where cultures and civilizations met. Throughout history, Mycenæans, Assyrians, Persians, Greeks, Romans, Byzantines, Franks, Venetians, Ottomans, British and Turkish have all been rulers of the island, leaving their marks not only on the landscape, but also on the local language. Contemporary Cypriot, a dialect of Modern Greek, displays indeed a considerable number of foreign words, in their majority of French, Italian, Turkish or English origin. The latter will be the focal point of this paper. In what follows, the different periods (and types) of linguistic contact between English and Cypriot Greek are juxtaposed, to afford us with a better appreciation of the extent of English influence on the Cypriot lexis.

\footnotetext{
Date of reception: July 2006

Date of acceptance and final version: September 2006

* Research Fellow, Department of Linguistics and English Language, University of Sussex; \stavrv@sussex.ac.uk
} 


\section{COLONISATION}

\subsection{Sociopolitical and cultural context}

In 1878, after an Anglo-Turkish convention, Cyprus was passed onto the British to become, in 1925, a Crown Colony, remaining as such until the independence of 1960. The takeover of the rule of Cyprus by the British was peaceful, but it had, once more, considerable effects on the ethnic composition of the population of the island. The British authorities carried out the first census of the population in 1881, according to which the total population was 186,173 , of which $137,631(73.9 \%)$ were Greeks, 45,438 (24.4\%) were Turks and $3,084(1.7 \%)$ were minorities of Armenians, Maronites and Latins. The main characteristic of the demographic constitution during the British occupation was the steady and continuous increase of the Greek population and the corresponding decrease of the Turkish one. In 1911 the total population was 274,108 inhabitants, in 1946 it was 450,114 and in 1955 it was 511,000; of which 409,822 (80.2\%) were Greeks, 97,090 (19\%) were Turks and 4,078 (0.8\%) were minorities (Hill 1952). The general increase of the population, despite the numbers of both Greeks and Turks that emigrated during the period, was due to the fact that the standards of living were immensely improved, as the British occupation brought an end to the oppression and precariousness of life, typical of the Turkish period. This was achieved mainly through the organisation of law and order and of the public service, including, most importantly, the health and education boards, and the financial policies of the British govern-ment that showed much more respect to the individual.

For the whole of the British period, Cyprus remained an agricultural country, farming being the main occupation of the population as well as the main source of the state's income. Trade was underdeveloped, though it was during this period that the mineral wealth of Cyprus was discovered and a new industry started to operate.

Education was an area which showed an impressive development during the period. In 1878 , by the end of the Turkish period, there were only 83 schools in Cyprus, all for primary education, and with an insignificant number of them in the countryside. This number was doubled in a period of five years, and by the twentieth century 322 schools were operating in Cyprus, both primary and secondary. The Greek students were receiving Greek education, and the schools were following the syllabi of the schools in Greece. Respectively, the Turkish students were receiving Turkish education. Both the Greek and the Turkish schools were subsidised from the corresponding communities, whereas teaching staff were brought from Greece and Turkey respectively. On the subject of instruction, Hunt says:

Education calls for special mention. In 1880 the High Commissioner, in a dispatch to the Colonial Secretary, proposed that for the future all education should be through the medium of English. This was consistent with policy in, for example, India. There, in the formative period of British rule, the authorities had positively favoured oriental languages, especially Persian; but Macaulay's famous minute [expressing his rejection of Sanskrit and, by implication, Persian, and his insistence upon English as the educational medium] and an advancing self-confidence had discarded Hafiz in favour of Wordsworth and Shakespeare. Lord Kimberley, Secretary of State in Gladstone's newly elected government, would not hear

Odisea, $\mathrm{n}^{\circ}$ 7, ISSN 1578-3820, 2006, 203-215 
of such treatment for Greek, which was still one of the two bases of British higher education. In a decision as important as any, and taken within two years of the occupation, he insisted that Greek should be the language of education throughout the island, with Turkish similarly used in the schools set up for the minority. From then on the schools for the majority followed the official Greek curriculum. As a result, the history and literature which children studied from their earliest youth were those of the mother country and the objects towards which their patriotism was directed were the Greek Royal Family and the Greek flag. (1990: 266)

In 1923 the domain of education passed under the control of the colonial government. Greek remained the language of instruction, and the only immediate consequence was the appointment of teachers as public servants. The teaching of English as a second language was not introduced until 1935, when the whole curriculum was revised.

During the period of the British occupation of Cyprus, the hitherto almost non-existent cultural life of the island was highly developed. In the same year of the change of regime (1878), the first printing press operated in Cyprus. The fact signalled the onset of Cypriot journalism, and the first newspaper, Kó $\pi \rho \varsigma_{-}-C y p r u s$, published by the scholar Th. Constantinides was broadly distributed. As its name suggests, this first newspaper was initially printed in both Greek and English (according to the terms assigned by the High Commissioner who sponsored the publication, G. Wolseley), but then in Greek only. Arnold comments:

For decades, this British colony did not have a newspaper in the English language, for who would need one? The people of the island were Greek or Turkish speaking; the English were a mere handful. Short-lived English newspapers did eventually make their brief appearance, only to die for want of circulation and finance. (1956: 16)

Several other Greek newspapers were soon to follow. At the beginning of the twentieth century, a number of literary magazines also appeared in public, with numerous poets and prose writers publishing their work, either in the local vernacular, which was encouraged, through broadcasting, by the British authorities as a means of promoting the separateness of the Greek Cypriots from their mother country, or in the Common Greek of the time (Katharevousa or Demotic, depending on the style and the formality of the text). Finally, theatre also made its appearance during this period, with several companies, both local and from Greece, performing all over the island.

Generally, the period of the British occupation, following a long period of obscurity, had some beneficial effects for Cyprus - reintro-ducing law and order, effective administration, education, generally the prospect of progress. 'The British occupation was not severe. They came and went, few knew whence and whither, least of all why', says Scherer (1997: 7). But he acknowledges the consequences: 'Cypriots credit the British with teaching them the value of education', he says elsewhere (1997: 78). And Hunt concludes:

The traces of British rule are naturally manifold. English is an official language. The law courts and the administration are British in inspiration. The largest colony of Cypriots abroad is in Britain, not Greece, mainly concentrated in London. Of material remains, such as an 
archaeologist of the future will unearth, the principal features will be sought in the infrastructure [...] (1990: 279)

In this brief historical narrative, we have paid particular attention to those factors that are in principle expected to have linguistic repercussions, such as demographic change and the constitution of the population at the new period of foreign rule, the several social institutions, the relationship and social interaction between the settled and the newcomers, or the standards of education and hence the levels of literacy of the local people. Such factual evidence will exemplify below how lexical changes are reflected symbiotically in the main political and social changes.

\subsection{Linguistic influence}

Historically, the English loanwords are the most recently borrowed by Cypriot Greek and, although significantly fewer in number than loanwords of other origin, they were established in Cypriot speech and are widely used. The colonisation of Cyprus by the British at the end of the nineteenth century introduced a new era to the island: there was, of course, a change in political power; but there was also the onset of a period where the native population, hitherto forced into stagnation by the oppressive Ottoman rule, would slowly start to 'catch up' with the industrial revolution that was well under way in Western Europe. New technologies, as well as institutions and practices were introduced to the island by the British and adopted by the Greek-speaking population along with their names. As in most cases of linguistic influence, certain areas of vocabulary have been particularly receptive. Therefore, the earliest borrowings are easily classifiable terms, as is shown below ${ }^{1}$ :

(a) Terms related to weaponry: machine gun > $\mu \alpha \sigma^{\prime} \gamma \kappa \alpha\left[\mathrm{ma}^{\prime} \int \mathrm{i}^{\mathrm{n}} \mathrm{ga}\right]$, sten gun $>$

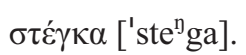

(b) Terms referring to types or parts of vehicles, and traffic or transport in general: clutch $>\kappa \lambda \alpha \check{\tau} \check{\zeta}[\mathrm{klat}]$ ], exhaust (pipe) $>\varepsilon \xi$ ós [e'ksos], spark (plug) $>$

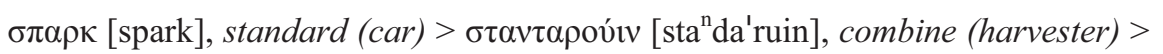
$\kappa \kappa о \mu \pi \alpha ́ l v$ [kko'mbain] - worth noticing is the process of clipping, i.e. the exclusion of a part of a longer form, that occurred in the adopted forms, whereby the Cypriot Greek speakers preserved only the item that carried the new, to them, notion; park $>\pi \pi \alpha \rho \kappa \alpha ́ \rho \omega$ [ppar'karo], parking $>\pi \pi \alpha ́ \rho \kappa ı$ ['pparkin].

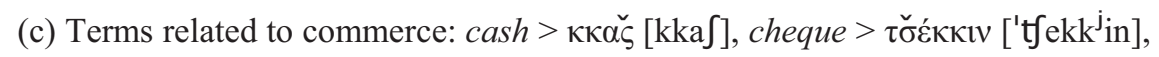
charge $>\tau \check{\sigma} \alpha \rho \tau \check{\sigma} \alpha \dot{\rho} \omega$ [t]ar't taro].

(d) Terms related to football: match $>\mu \alpha \check{\tau} \check{\zeta}[\mathrm{mat}]$, back (player) $>\mu \pi \alpha \kappa\left[{ }^{\mathrm{m}} \mathrm{bak}\right]$,

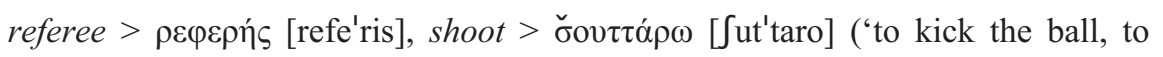

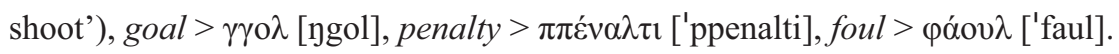

\footnotetext{
${ }^{1}$ Cited words are based on the early records of Hadjioannou (1996; based on 1936) and Iakovou (1993).

${ }^{2}$ This may also be derived from the English make of car Standard; cf. Cypriot $\mu$ ivov́( $\delta$ )เv, from Mini, or

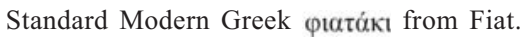

Odisea, $n^{\circ} 7$, ISSN 1578-3820, 2006, 203-215 
(e) Other English words, notably polysemic, that passed into the dialect only with the meaning that was first conveyed, or that introduced a new concept at the

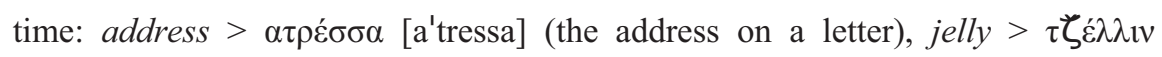

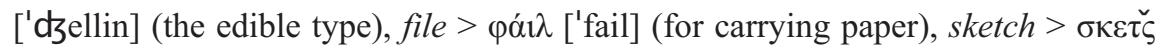

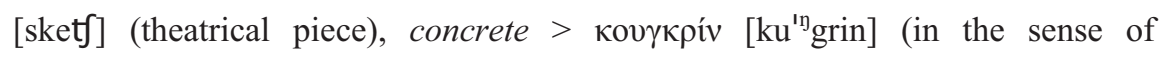
'cement'), bailiff $>\mu \pi \dot{\varepsilon} \lambda_{1} 1 \varphi$ ['mbeilif], (referring to a legal officer); only exception:

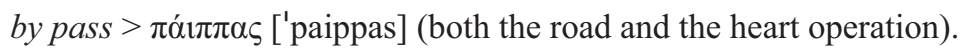

A number of verbs were also borrowed from English, even though the number of the English loanwords is relatively small, and despite the general claim on the limited 'borrowability' of verbs, as opposed to nouns (Hock 1991; Trask 2000). Such verbs include the following: cancel $>\kappa \kappa \alpha \sigma \sigma \varepsilon \lambda \lambda \dot{\alpha} \rho \omega$ [kkassel'laro], confirm $>\kappa \kappa о \varphi \varphi \varepsilon \rho \mu \alpha ́ \alpha \omega$

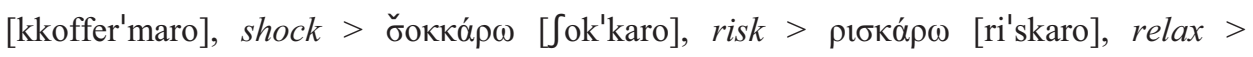
$\rho \imath \lambda \alpha \xi \dot{\alpha} \rho \omega$ [rilak'saro], test $>\tau \tau \varepsilon \sigma \tau \dot{\alpha} \rho \omega$ [tte'staro], train $>\tau \rho \varepsilon v \alpha \dot{\alpha} \rho \omega$ [tre'naro], check $>$

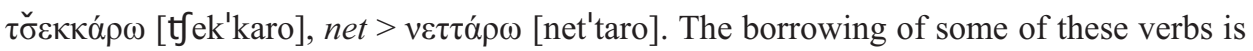
evidently expectable, considering that they are often heard in an office environment or some other business-like context.

\subsection{Comparative evaluation}

As mentioned above, the English language gave Cypriot Greek far fewer loanwords, in comparison with the other languages that the dialect came into contact with as a result of invasion, conquest or settlement. Turkish, the most 'generous' of the donor languages, has enriched the local vocabulary in an impressive, unprecedented way - not surprisingly considering the length of the Ottoman rule on the island (1571-1878). Venetian, alongside some other Italian dialects, would hold the second place among the sources of foreign items in the Cypriot lexicon, despite the fact that the Venetian rule was of approximately the same length as the British one (1489-1571). And during the political period immediately before that (the Lusignan period, 1191-1489), the strong influence of Provençal and French was so profound, that written documents of the time appear to be written in a hybrid Frankish-Greek tongue and that, perhaps unsurprisingly, a considerable number of related loans survived in the contemporary dialect, fully nativised and indistinguishable from the native stock (Varella 2006).

The duration of language contact situations can only be party responsible for the degree and intensity of linguistic influence during each particular period. The demographics of the relevant historical periods are perhaps more important in quantifying linguistic interference, in elucidating, that is to say, why some languages have been more 'openhanded' than others.

Unlike the colonial rule of the British, all previous political powers introduced drastic changes to the composition of the island population, in that each change in political power was accompanied by population movement and settlement. First, the Lusignan 
dynasty, in its effort to establish control over Cyprus, invited people of alike ethnic background, lan-guage, or religion to reside on the island, offering them fiefs and offices. Four Latin bishoprics were founded and a number of military religious orders were also established. A wealthy urban class of European merchants was soon formed and, while the subjected Greeks found themselves in the lowest social strata, the newly-formed feudal kingdom secured the basis of steady development. The several socioeconomic strata typically found in medieval feudal societies were also divided along cultural and linguistic lines too. On the whole, medieval Cyprus possessed many of the characteristics of direct linguistic contact: a Fishman (1980)-type diglossia of two distinct intra-group codes was arranged between the subjects and the rulers; bilingualism obtained among the middle classes; and acquisition of the 'ruling' language became a prerequisite for upward social mobility.

Second, the Venetians had already acquired significant status in the Frankish kingdom of Cyprus, having established large and economically powerful communities in the major towns of the island, where they were primarily engaged with the trade between West and East, with Cyprus as a transit stop. Support from Venice itself, made the Venetian community of Cyprus a 'state within a state', until 1489 when Venice officially took control of the island. Subsequently, the Republic developed a policy of repopulating her newly acquired colony, from purely economic motives, driving population from Venice and its other colonies. Around $20 \%$ of the total population consisted of ethnically and linguistically heterogeneous town-dwellers, in their majority Italian and, despite the urban and mercantile nature of Venetian rule, there also existed a number of Italian villages.

Finally, the Ottoman conquest introduced even more dramatic changes in the constitution of the population. While the remained European inhabitants assimilated to the Greek population, the introduction of a Turkish minority, initially composed of about 3,500 soldiers, would soon develop into what came to be known as Turkish Cypriot community. A census carried out towards the end of the Ottoman rule refers to the population as 165,000 - of which 120,000 were Greeks, 44,000 Turks, and 1000 mixed minorities of Catholics and Armenians (Papadopoulos 1965).

As described previously, the period of British colonial administration shows none of the settlement patterns characteristic of the preceding historical periods. The Englishspeaking population was limited to colonial officials, diplomats and the military personnel and, consequently, the interaction between native English and native Greek speakers was limited to specific circles only.

We have also illustrated in the first section that the British administration had little concern in imposing English as the medium of instruction. For the colonialists, Greek hold an intellectual status that could secure its functional dominance in the field of education. For the native population, on the other hand, Greek assumed a new role, acquiring, perhaps for the first time in history, a symbolic status, whereby language and national identity became synonymous. As nationalism was rising, so was resentment against the colonial power and rejection of all its representations. The English language became a symbol of oppression, whereas Greek was associated with liberation and concurred with the aspirations of the Cypriots to unify their island with mainland Greece.

Odisea, $\mathrm{n}^{\circ}$ 7, ISSN 1578-3820, 2006, 203-215 
In contrast, Imperial English acquired a completely different status in most of the other British colonies. In many, it divided societies into native-speaking majorities and English-speaking elites, thus becoming a symbol of power, social advancement and progress. In other societies, already divided on ethnic grounds, English offered an escape route from internal conflicts, serving as a neutral language that could unify the population. In such countries as India, Pakistan, Nigeria and Ghana, English is, to this day, more widely acceptable than the local alternatives. In most of the former colonies, English continues to dominate politics, education and law decades after independence; in a significant number of countries still, it maintained its official status.

Whereas bilingualism in English and another tongue became a permanent feature almost throughout the British Empire, it was almost non-existent in colonial Cyprus. To illustrate, let's recall the aforementioned piece of evidence that the British administration had failed to establish an English-language newspaper in Cyprus. In contrast, Nigeria, the largest Anglophone Black African country, has fourteen dailies; one of the smallest, Gambia, has eight. In Zimbabwe and Zambia, both daily newspapers still appear in English. Hong Kong maintained five papers, whereas in India there are six dailies based in New Delhi alone, more to be found in other cities (McArthur 2003).

It is not easy of course to assess the extent of the intellectual, social and cultural hegemony exerted by the English language in different parts of the world. History is too recent to make any definitive claims, and linguistic attitudes are mixed. Intellectuals from some post-colonial zones warn that English might be a Trojan horse given to the postcolonial world, usually in the light of newly-formed nationalisms. On the other hand, policy-makers across the board regard English as a great gift, which was left as a compensation for the ill-fated past. In this view, the former colonies regard themselves as better-equipped to cope with the continuously globalising state of the modern world.

\section{INTERNATIONALISATION}

\subsection{Sociopolitical and cultural context}

Immediately after Cyprus received its independence in 1960, a process of modernisation began. Steady economic growth became a feature of the post-colonial society; in the early 1970s, for example, the economy was thriving with an annual economic growth of $7 \%$ (Symeonides 1977).

The Turkish invasion in 1974 effectively partitioned the island's economy. The economy of the Greek south had to recover from the heavy blow caused by the occupation of the north. And it did so successfully: figures are indeed indicative of a miraculous recovery. While immediately after the partition in 1975 the gross domestic product dropped by $33 \%$, from that year until 1978 it showed a constant annual average rise of $7 \%$ by the end of the same year the south had managed to attain full employment. (Christodoulou 1992).

During the years after partition, the south promoted many infrastructural projects aimed at both reactivating the economy and at integrating the refugees into the local work cycle. Thus, two new airports were constructed, a number of water projects have been 
created, the first motorway and new secondary roads were built, new housing and industrial estates constructed, and the expansion and modernisation of the two main ports and telecommunication systems was carried out (Hudson and Dymiotou-Jensen 1989). Amongst all the redeveloping economic sectors, tourism was assigned as the leading sector.

Today, Cyprus has one of the most successful economies in the western developed world, with still high annual growth rates and full employment. It has managed to introduce tertiary economic sectors and its offshore and finance business are flourishing. Over the last few decades, Cyprus has become a centre of transit trade, international merchant shipping and business, a key outpost in the Eastern Mediterranean that serves as a bridge between the EU and the Middle East.

The island is now established as one of the leading maritime centres of the world. More than 45 ship-management companies and marine-related offshore enterprises conduct their international activities on the island, and most of the largest ship-management companies in the world have established fully-fledged offices on the island (Press and Information Office 2005).

The latest technology has been successfully integrated in the economy. Based on the results from the 'Information and Communication Technologies Usage and E-Commerce in Enterprises' annual survey, the percentage of enterprises that used a computer in 2005 is $93.9 \%$. Use of ICT by the broader society is also on the increase: results from the 'Information and Communication Technologies Usage in Households' annual survey indicate the percentage of households that have a computer has reached $46.4 \%$ (The Statistical Service 2005) .

Such trends are indicative of the way that English, the language of international trade, business, finance and technology has penetrated the Cypriot society. What is more, the arrival of English-speaking people on the island is also significantly contributing to the continuous spread in the use of English. The number of immigrants is considerable 22,003 in 2004 alone (The Statistical Service 2005), while the composition of the immigrant population is of great importance: expatriated Brits arriving for permanent settlement; repatriated Cypriots or people of Greek-Cypriot descent, in their majority having English as their first language; foreign investors from across the globe, and workers mainly from Asia and Eastern Europe - two groups who would depend on use of 'global' or 'lingua franca' English for their daily affairs.

Local institutions have responded successfully to the needs of the increasing Englishspeaking population of the island. Today there are several English-language radio channels, whereas the public broadcaster, Cyprus Broadcasting Corporation, caters for its Englishspeaking audience across its television and radio channels, with news bulletins and other special programming. With regards to the print media, there are three English-language newspapers on the island, a news daily, a news weekly and a business weekly, all privately owned by Cypriot companies.

The English language has also consolidated its position in the education sector. English is today the first foreign language taught in Cypriot schools from the third grade of the elementary school to the end of the secondary school. English is the language of instruction in almost all private and in some public tertiary institutions, while the creation of Englishbased elementary (and even nursery) schools is on the increase.

Odisea, $\mathrm{n}^{\circ}$ 7, ISSN 1578-3820, 2006, 203-215 


\subsection{Linguistic influence}

The wide use of English on the island, along with the almost exclusive association of the language with advancements in technology, business and commerce, is accountable for the second phase of lexical borrowing from English. The new contact situations have indeed resulted in an additional number of English loanwords in Cypriot Greek. Below I cite a representative sample of such words, grouped together according to the spheres of influence they represent. ${ }^{3}$

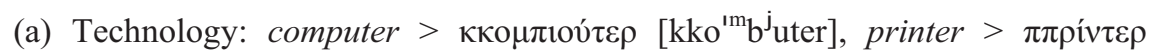

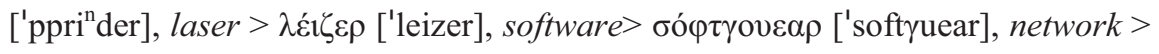

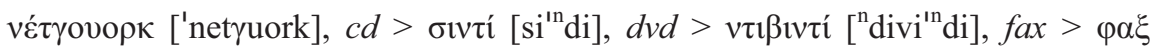

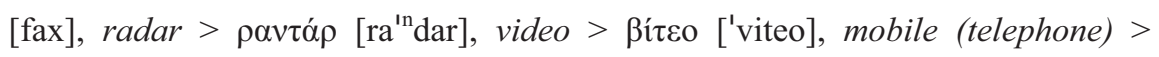

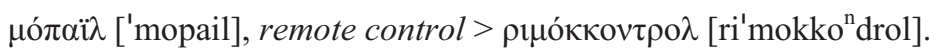

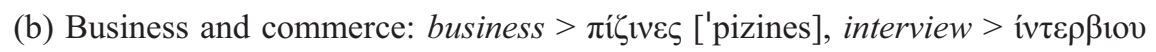

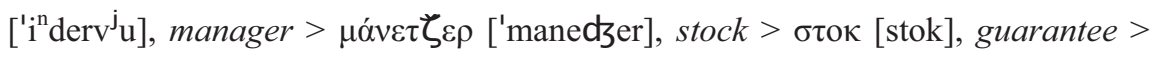

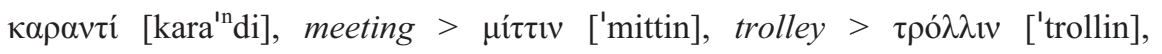

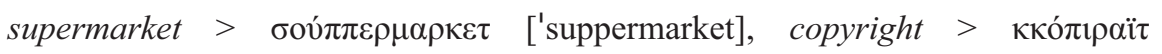
['kkopirait], register $>\rho \varepsilon \tau \zeta$ $\sigma \tau \rho \alpha ́ \rho \omega$ [redzi'straro].

(c) Tourism: canteen $>\kappa \alpha \tau \tau i ́ v \alpha$ [kat'tina], bar $>\mu \pi \alpha \rho\left[{ }^{\mathrm{m}} \mathrm{bar}\right]$, barman $>\mu \pi \alpha \dot{\alpha} \rho \mu \alpha \nu$

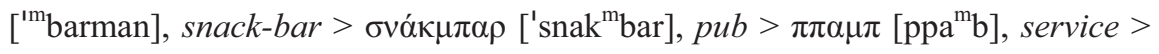

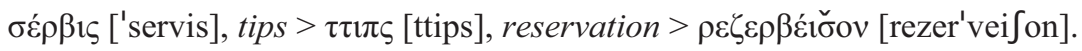

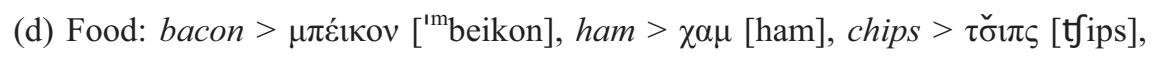

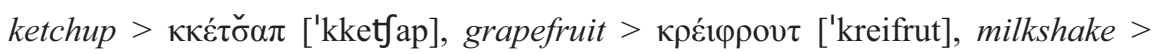
$\mu$ ['kkofleiks].

In addition to these culture-specific terms, there exist a few English words that became an almost permanent feature of daily informal interactions between Cypriots. Most evidently heard in telephone conversations, but also in other encounters, these

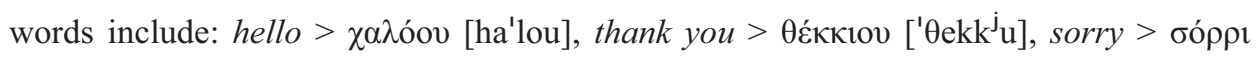

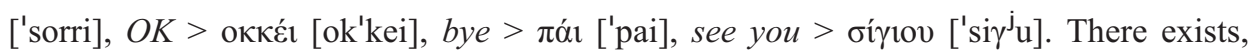
therefore a tendency for tag-switching or, according to Goutsos (2001), a specific type of language alternation that is context-dependent and that signals sequential relations within spoken discourse.

\footnotetext{
3 While the number of loans is undoubtedly on the increase, it is worth referring to Papapavlou's 1997 study: the author collected over 400 terms, but a closer linguistic investigation reveals indeed that many of these concern English loans filtered through French or Italian; some others are perhaps not English at all, but French or of other origin that were also borrowed into English; other words, still, are certainly of English origin, but it is doubtful whether they were borrowed through direct contact between the Cypriot dialect and English, or through influence from Standard Modern Greek.
} 


\subsection{Comparative evaluation}

From the above outline of English's impact on contemporary Cypriot speech, it is the lastly mentioned engagement in tag-switching that has been most suggestive of an influence of a great extent. 'The use of English is so widespread that Greeks usually say you can always identify Greek Cypriots by their use of English expressions', says Karyolemou (2001: 30). Within Cyprus, purists and xenophobes see in this apparent conversational code-switching the onset of a detrimental hybridisation of the local speech. '[They] argue that an Anglo-Cypriot idiom has been created that is slowly replacing the Greek dialect and, as a consequence, weakening the Helleno-patriotic feelings of Cypriot society and eroding and eradicating its national identity', summarizes Papapavlou (2001:169). Ioannou (1991), for instance, expresses fears for 'corrupted linguistic expression' and warns against reverting to 'disastrous colonial models of language and culture' (1991: 38). Likewise, Karoulla-Vrikkis (1991) discusses the emergence of a new 'creole' and its implications for social and ethnic identity. Disparaging views concerning linguistic issues, and especially the degree of lexical borrowing, abound public opinion; an investigation into the largest Cypriot newspaper revealed that a relevant article would appear as often as every four days in the mid-nineties, compared every two months twenty years before that (Karyolemou 1994).

It goes without saying that most of such sceptic and hyper-critical commentary lacks any empirical evidence, for an issue that is in itself very controversial and way too soon to assess. In fact the only empirical studies aiming at an evaluation of lexical borrowing in Cypriot Greek point at the opposite direction. In an attitudinal study Papapavlou (1988) showed that borrowing and use of foreign expressions is encouraged by positive feelings towards overseas people and their languages. In another attitude survey McEntee-Atalianis and Pouloukas (2001) revealed both a positive stance towards the use of English, and an almost universal legitimacy of its value for social and economic advancement.

With regards to reactions against the extent of borrowing from English, it is worth noting that despite the historical links between Cyprus and Britain, the present situation shows no difference to other countries that have only recently been into contact with the emerging international variety of English. Fearful statements have been voiced across the globe: both in Europe, where concerns may be rather expected given it is the birthplace of such notions like 'nation-state' and 'national language' (see e.g. Ammon 1994), and further afield (see e.g. Honna 1995).

With regards to the spread of English and the impact it exerts on other languages, it is arguable that the language has secured its role as an international medium of communication. 'A language has traditionally become an international language for one chief reason', says Crystal, 'the power of its people -especially their political and military power' (2003: 3). This is historically the case for English, the spread of which can be attributed first to the colonial expansion of the British Empire in the nineteenth century, and second to the emergence of the US as the leading power of the twentieth century. Other scholars predict that English is 'here to stay'. Graddol (2000), for example, supports that argument with evidence from the ENGCO model -a tool that measures the global influence of the major languages based on economic factors, including the 'gross language product' and the

Odisea, $\mathrm{n}^{\circ}$ 7, ISSN 1578-3820, 2006, 203-215 
openness to world trade, demographic factors like numbers of young speakers and rates of urbanisation, and the human development index for different countries. According to the model, English is a long way ahead of all the other major languages, including Chinese.

In conclusion, it may be safe to argue that any attempts to stem the present tide of Anglicisms from flowing the world's languages should rest in the hands of policy makers and authoritative gate-keepers. It might be possible to control the number of neologisms entering a language through considerate language planning, but even that often seems to be a notorious affair. The Académie Française has gone so far as to substitute the use of such common English words and phrases as software and walkman with the French equivalents logiciel and baladeur; and yet the first 'Globish' (for global English) manual, a 1500-word list, was invented by a Frenchman, Jean-Paul Nerrière, in 2004. It now appears to be circulating across the world...

\section{REFERENCES}

Ammon, U. 1994. 'The present dominance of English in Europe. With an outlook on possible solutions to the European language problems'. Sociolinguistica 8: 1-14.

Arbel, B. 2000. Cyprus, the Franks and Venice. Aldershot.

Arnold, P. 1956. Cyprus challenge: A colonial island and its aspirations. London.

Christodoulou, D. 1992. Inside the Cyprus miracle - The labours of an embattled mini-economy. Minneapolis.

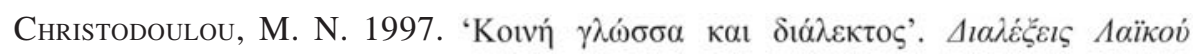

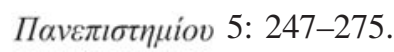

Совнам, C. D. 1908. Excerpta Cypria: Materials for a history of Cyprus. Cambridge.

CRYSTAL, D. 2003. English as a global language. Cambridge.

Fishman, J. A. 1971. Advances in the sociology of language. The Hague. Wiesbaden. 1980. 'Prefatory notes'. Languages in contact and conflict. Ed. P. H. Nelde.

Goutsos, D. 2001. 'A discourse-analytic approach to the use of English in Cypriot Greek conversations'. International Journal of Applied Linguistics 11: 194-223.

GradDOL, D. 2000. 'English in the future'. Analysing English in a global context. Ed. A. BuRns. London.

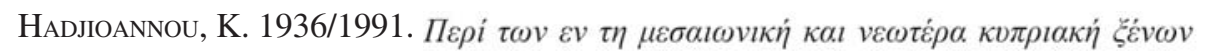

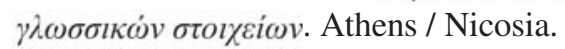

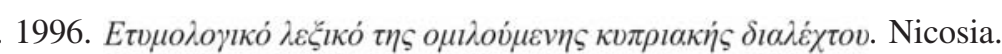

Haugen, E. 1950. 'The analysis of linguistic borrowing'. Language 26: 210-231.

HeAth, J. G. 1984. 'Language contact and language change'. Annual Review of Anthropology 13: 367-384.

Odisea, $\mathrm{n}^{\circ}$ 7, ISSN 1578-3820, 2006, 203-215 
HiLl, G. 1948, 1952. A history of Cyprus. Vols. 3 and 4. Cambridge.

Hock, H. H. 1991. Principles of Historical Linguistics. Berlin.

HonnA, N. 1995. 'English in Japanese society: Language within language'. Journal of Multilingual and Multicultural Development 16: 45-62.

Hudson, J. and M. Dymiotou-Jensen. 1989. Modeling Developing Country. Middlesex.

Hunt, D. 1990. Footprints in Cyprus: An illustrated history. London.

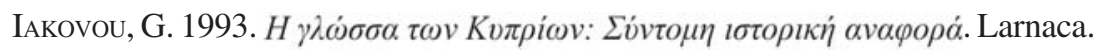

IoAnnou, Y. E. 1991. 'Language, politics and identity. An analysis of the Cyprus dilemma'. The Cyprus Review 3, 1: 15-41.

Johanson, L. 2002. 'Contact-induced change in a code-copying framework'. Language Change: The interplay of in-ternal, external and intra-linguistic factors. Eds. M. C. Jones and E. Esch. Berlin. 285-313.

KAROUlla-VRIKKI, D. 1991. 'The language of the Greek Cypriots today: A revelation of an identity crisis. The Cyprus Review 3, 1: 42-58.

Karyolemou, M. 1994. 'Linguistic attitudes and metalinguistic discourse: An investigation in the Cypriot press'. Themes in Greek Linguistics. Ed. I. PHILIPPAKIWartburton, K. Nikolaidou and M. Sifianou. Amsterdam. 253-259.

. 2001. 'From linguistic liberalism to legal regulation. The Greek language in Cyprus'. Language Problems and Language Planning 25: 25-50.

KIRRIS, C. P.1985. History of Cyprus. Nicosia.

LuKE, H. 1921. Cyprus under the Turks: A record based on the archives of the English Consulate in Cyprus under the Levant Company and after. London.

Maltezou, C. 2000. 'Franks and Venetians in Cyprus'. Cyprus: A civilization plundered. Ed. The Hellenic Parliament. Athens. 96-106.

MCARTHuR, T. 2003. Oxford Guide to World English. Oxford.

Mcentee-Atalianis, L. and S. Pouloukas. 2001. 'Issues of identity and power in the Greek Cypriot community'. Journal of Multilingual and Multicultural Development 22: $19-38$.

PANDELI, S. 1984. A new history of Cyprus. London.

PAPADOPOUlOS, Th. 1965. Social and historical data on population: 1580-1881. Nicosia.

Papapavlou, A. N., 1988. 'Motivational, attitudinal and socio-cultural factors in lexical borrowing'. Journal of Business and Society 1,2: 151-163.

- 1994. Language contact and lexical borrowing in the Greek Cypriot dialect: Some socio-cultural implications. Nicosia.

1997. 'The influence of English and its dominance in Cyprus'. Journal of Mediterranean Studies 7: 218-249. 
. 2001. 'Linguistic imperialism? The status of English in Cyprus'. Language Problems and Language Planning 25: 167-176.

Press \& Information Office, Republic Of Cyprus. 2005. Cyprus: One of the leading maritime centres of the world. <http://www.moi.gov.cy/moi/pio/pio.nsf > .

PurCell, H. D. 1969. Cyprus. London.

SCHERER, J. L. 1997. Blocking the sun: The Cyprus conflict. Minneapolis.

Statistical Service, RePUblic OF CypRUs. 2005. Demographic Report.

2005. ICT usage and E-commerce Enterprises.

2005. ICT usage in households and by individuals. <http://www.mof.gov.cy /mof/cystat/statistics.nsf >.

Symeonides, N. S. 1977. 'The unity of the economy and the economics of separation'. Cyprus Reviewed. Ed. M. A. Attalides. Nicosia. 255-271.

Thomason, S. G. 2001. Language Contact. Edinburgh.

Thomason, S.G. and T. Kaufman. 1988. Language Contact, Creolization and Genetic Linguistics. Berkeley.

Trask, R. L. 2000. The Dictionary of Historical and Comparative Linguistics. Edinburgh.

VARELLA, S. 2006. Language contact and the lexicon in the history of Cypriot Greek. Bern.

WeinReich, U. 1963. Languages in contact: Findings and problems. The Hague.

Whitney, W.D. 1881. 'On mixture in language'. Transactions of the American Philological Association 12: 1-26.

WINTER, W. 1973. 'Areal Linguistics: Some general considerations'. Current Trends in Linguistics II: Diachronic, Areal and Typological Linguistics. Ed. T. S. Sebeok. The Hague. 135-147.

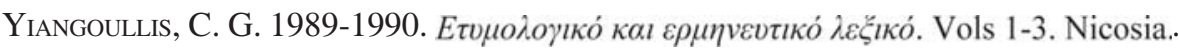
Vols 1-3. Nicosia.

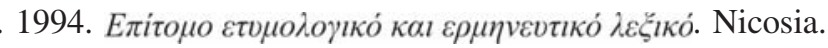

